\title{
OBITUARY
}

\section{John Gray Aldous (1916-2002)}

Dr. John Gray Aldous passed away peacefully on April 5, 2002 in Halifax. Born on November 16, 1916 in Bristol, England he moved to Canada with his family in 1919 and spent his formative years in Victoria. He attended Victoria College, then part of the University of British Columbia (UBC), and graduated from UBC with a B.A. in 1939 and M.A. in 1941. He completed his PhD in physiology at the University of Toronto in 1945 after investigating the action of narcotics in living cells.

That same year John moved to Halifax with his wife, the former Eileen Hooley of Vancouver whom he had married in 1944. There he took up an appointment as assistant professor in the Department of Pharmacology, Faculty of Medicine at Dalhousie University. His arrival swelled the ranks of the young department to two. Although somewhat nervous in his new appointment because he had never had a course in pharmacology or medicine, he learned quickly through his teaching. He gave the first class in dental pharmacology in 1947, the first undergraduate class in pharmacology to science students in 1950 and was instrumental in establishing the graduate program in pharmacology. Dr. Aldous was promoted to associate professor in 1948, and full professor and Head of the Department of Pharmacology in 1950, a position he held for twenty-five years. During this period, the department expanded markedly and moved from the old Medical Sciences Building into the new Sir Charles Tupper Medical Building. In 1981 he retired and was appointed Professor Emeritus. Throughout his 36-year career with the Department of Pharmacology, Dr. Aldous was a well-respected teacher and administrator who provided strong leadership to Dalhousie University. Mild-spoken and even-tempered, he formed close friendships with many of his students and took great pride in their accomplishments. In honour of his many contributions, the Department of Pharmacology established the Aldous Prize which is given annually to the best student in the undergraduate science pharmacology course.

For many years John Aldous was an active member of the Nova Scotian Institute of Science: Corresponding Secretary in 1948-1951, Vice President in 1954-1956, and President in 1956-1958. In 1953 he published the first cumulative index of the Proceedings of the Nova Scotian Institute of Science (1865 to 1950). In recognition of his many contributions, he was made an Honorary Life Member.

Dr. Aldous was also a member of the Canadian Physiological Society, Pharmacological Society of Canada, Biological Council of Canada, Nova Scotia Commission on Drug Dependency, Nova Scotia Pharmacy Society, Nova Scotia Heart Foundation, Alpha Omega Alpha Honor Medical Society, and Phi Rho Sigma Medical Society. In addition to his many scientific interests, John had a strong love of the out-of-door. He particularly enjoyed the spring fishing trips down the Eastern Shore with his medical colleagues in the Izaak Walton Club immediately after exams were graded. John and his wife Eileen were strong supporters of the music community in Halifax.

Eileen Aldous was killed in a tragic car accident in October 1969 and for many years Dr. Aldous was a widower. Soon after he retired from Dalhousie, he moved to his son's farm in Hants County to take up the life of a country gentleman. In 1985, he re-married and moved to Vancouver where he enjoyed a new life in old surroundings. After the death of his second wife in 1997, he returned to Nova Scotia to spend his final years 
close to his three children (Joleen Gordon, Peter Aldous and Don Aldous) and their families. A celebration of his life was held in the Great Hall of the Dalhousie University Club on Saturday May 18, 2002. According to his wishes, his ashes have been dispersed at special places in British Columbia and Nova Scotia.

Prepared by his daughter Joleen and her husband Donald C. Gordon. 